\title{
AGORA: REFLECTIONS ON RJR NABISCO V. EUROPEAN COMMUNITY
}

\section{A EUROPEAN STORY}

\author{
Stephanie Francq*
}

The decision of the Supreme Court in RJR Nabisco v. European Community is the culmination of sixteen years of litigation, preceded by years of investigation. From a European perspective, the decision can only be read as a disappointment: "we" tried, "we" lost. But beyond the frustration with the outcome, this European take on the RJR decision will focus on two questions: (i) why did the European Community decide to bring proceedings in the United States in the first place; and (ii) what would happen in the reverse scenario, if a foreign public authority or a private plaintiff were to bring suit in the European Union? Answering these two questions casts RJR in a slightly different light and offers an interesting picture of the wider political and regulatory context in the European Union.

\section{RJR and the Development of EU Criminal Law: What if Nabisco Had Been Sued in the European Union?}

As Justice Ginsburg pointed out, "this case has the United States written all over it." But the case also has the European Union written all over it. The facts underlying the case (cigarette and narcotics smuggling, black market, money laundering, evasion of customs duties and taxes) took place largely in the European Union, where they of course constitute severe criminal offenses and tax fraud. Why did the European Union (back then still the European Community) ${ }^{2}$ and its Member States decide to litigate in the United States when the functions of the public authority and the protection of the EU budget were so clearly at stake?

The promise of treble damages was probably part of the legal strategy. Treble damages are not only lucrative, they are also punitive and exemplary. Putting a few people in prison in Europe, however, might have provided a deterrent as well. Another incentive for pursuing the litigation in the United States was the location of the defendant: it seems both fair and efficient to litigate against a U.S. company in the United States. But as a public authority, wouldn't the first answer to crime be a criminal prosecution in its own courts? As a matter of fact, even today, the European Union has no authority at the "federal" Union level to prosecute similar crimes and recover the allegedly lost revenue suffered by the European Union. The facts at the heart of RJR would trigger criminal and administrative proceedings spread throughout the territories, and among the public authorities, of many different Member States and be subject to only partially harmonized national laws. It is only more or less since the RJR case began that regulations in the European Union are starting to change this framework.

* Université Catholique de Louvain. I would like to thank. Claudia Hahn, Peter Jozsef Czonka, and Zachary Clopton for helpful conversations on this case.

Originally published online 09 August 2016.

${ }^{1}$ RJR Nabisco, Inc. v. European Community, 136 S. Ct. 2090, 2115, slip op. at 7 (2016) (Ginsburg J., dissenting).

2 The European Community has been replaced by the European Union when the Treaty of Lisbon entered into force in 2009 . For the purpose of simplification, I refer to the European Union throughout this contribution. 
Outside the field of competition law, the European Union does not have its own administrative, let alone criminal, authorities with full executive powers. The implementation of EU law, and thus the pursuit of the breaches of EU law by private actors, generally falls within the responsibility of Member States. ${ }^{3}$ For instance, national authorities collect taxes and custom duties, and thereafter transfer to the European Union the funds that constitute its budget. The decentralized application of EU law explains why the protection of the European Union's financial interests has been a recurring problem, subject in the last twenty years to multiple legislative initiatives. This problem, together with the fight against international organized crime and terrorism in an open market, has prompted the development of EU criminal law. All of this is at the heart of the RJR litigation.

In 2000, when the RJR litigation began, the debate concerning the protection of the European Union's financial interests through criminal law was at a crossroads. At the substantive level, protection of the European Union's financial interests was mainly addressed by the "PIF Convention." 4 Under that Convention, which only entered into force in 2002, Member States had committed to penalize fraudulent behavior affecting the financial interests of the European Union. Other instruments provided a first layer of harmonization and coordination among Member States in the field of criminal law, including money laundering. ${ }^{5}$ Yet their wording was vague and they did not establish uniform criminal penalties. At the procedural level, the European Anti-Fraud Office (OLAF) was set up in 1999 and given administrative but not criminal investigation powers. ${ }^{6}$ Even today, OLAF cannot initiate criminal proceedings in a Member State or at the "federal" level. OLAF can merely inform national public prosecutors, who then determine whether to bring criminal charges. ${ }^{7}$

Had the European Union decided in 2000 to go after Nabisco in the European Union, it would have been dependent on the willingness of national criminal and/or administrative authorities to bring such charges before Member State courts and it would have faced a series of practical difficulties. Coordination of the criminal proceedings launched in the various Member States was not yet officially organized. It was only in 2002 that the Member States set up Eurojust, a special unit composed of national judges and prosecutors established to advance judicial cooperation in criminal matters. ${ }^{8}$ There was no uniform standard as regards the admissibility of evidence, even evidence gathered by OLAF. The reach of the national proceedings would have been limited by the territorial jurisdiction of national authorities. Even under the PIF Convention, the jurisdictional rules were the object of various understandings among Member States. ${ }^{9}$ And the criminal penalties imposed by

\footnotetext{
${ }^{3}$ The European Commission has the authority to launch infringement procedures only against Member States (Consolidated Version of the Treaty on the Functioning of the European Union art. 258, May 9, 2008, 2008 O.J. (C 115) 47.

${ }^{4}$ Convention of 26 July 1995 on the protection of the European Communities' financial interests 1995 O.J. (C 316$) 49$ and its three additional protocols 1996 O.J. (C 313) 1; 1997 O.J. (C 221) 11; 1997 O.J. (C 151) 1. Council Regulation 2988/95 on the protection of the European Communities' financial interests, 1995 O.J. (L 312) 1, providing for basic administrative penalties.

5 See Second protocol attached to the PIF Convention 1997 O.J. (C 221) 11; A first directive concerning the danger of money laundering within the realm of the internal market had already been enacted in 1991: Council Directive 91/308 of 10 June 1991 on prevention of the use of the financial system for the purpose of money laundering, 1991 O.J. (L 166) 77; for the latest version of the directive: Directive 2015/849, 2015 O.J. (L 141) 73.

${ }^{6}$ Commission Decision of 28 April 1999 establishing the European Anti-Fraud Office art. 2(1), 1999 O.J. (L 136) 20.

${ }^{7}$ Regulation $883 / 2013$ of 11 September 2013 concerning investigations conducted by the European Anti-Fraud Office (OLAF) artt. 2(4), 11, 2013 O.J. (L 248) 1.

${ }^{8}$ For more info see EUROJUST; Europol is this corresponding unit concerning cooperation among polices, see EUROPOL.

${ }^{9}$ Report from the Commission on the implementation by the Member States of the European Communities' financial interests and its protocols 6 para. 3.3, COM (2004) 709 final (Oct., 25, 2004).
} 
Member States under the Convention differed significantly. ${ }^{10}$ It is therefore not surprising that the European Union (back then the European Community) favored a single proceeding that it could control. ${ }^{11}$

The European Union's legal strategy proved efficient. RICO litigation in the United States was initially commenced against a series of cigarette producers. All of them, except Nabisco, concluded "agreements" with the European Community and its Member States under which they were to pay over two billion dollars to the European Union and undertake a series of actions for combatting illegal trafficking in their products. ${ }^{12}$ The European Union's agreement with Philipp Morris was in effect until July 9, 2016. The European Commission decided not to renew it and to focus instead on a strategy of "strict law enforcement and strengthened international cooperation."13 The European Parliament had earlier questioned the agreement's necessity and compatibility with the European Union's "market and regulatory environment." 14

Is the European Union on the verge of adopting a RICO-style regulation? Not quite, but the situation has certainly changed since 2000. The European Union has developed a comprehensive strategy to fight against tobacco smuggling and its collateral health and financial effects via investigation, coordination of national seizures, and the enactment of legislation. ${ }^{15}$ But, more importantly, the entry into force of the Lisbon Treaty permitted the revival of two major projects: the PIF Directive and the European Public Prosecutor. ${ }^{16}$ In 2000, when the RJR litigation was launched against Nabisco, the Commission was already calling for these innovations. ${ }^{17}$ The PIF Directive will replace the PIF Convention and bring a sensibly higher degree of harmonization to the legal systems of Member States concerning, for instance, the definition of fraud, the level of sanctions, and statutes of limitations. The proposal to establish the European Public Prosecutor's Office, a proper EU authority charged with investigating and prosecuting crimes affecting the European Union's financial interests, would give teeth to the PIF Directive. The Office would be composed of national prosecutors working in their respective Member States, but as truly "federal" authorities with independent power to press charges before national courts. Also pending is a proposal for improving the functioning and structure of Eurojust. ${ }^{18}$ The whole legislative package is expected to be adopted by the end of 2016. It will provide and offer exactly what was missing in 2000.

The availability of treble damages was thus far from a complete explanation for the European Union's decision to pursue the RJR litigation. The behind-the-scenes aspects of the RJR litigation implicates the whole history of EU criminal law: the first attempts, with limited success, to give the European Union a criminal jurisdiction; the on-going concerns about organized crime, smuggling, and the protection of the European

${ }^{10} \underline{I d}$. at 7 para. 3.4 .

${ }^{11}$ Litigating in the United States for damages rather than introducing criminal procedures also had the advantage of lowering the standard of proof.

12 The text of the agreements can be found at Tobacco Smuggling, OLAF.

${ }^{13}$ Kristalina Georgieva, Expiry of the agreement with Philipp Morris International, EuropeAn COMMISSION (July 6, 2016).

${ }^{14}$ European Parliament resolution of 9 March 2016 on the tobacco agreement (PMI agreement), Eur. PARL. Doc. P8_TA(2016)0082.

${ }^{15}$ For more details, see Questions and answers on fighting the illicit trade of tobacco product, (Aug. 14 2015).

${ }^{16}$ Proposal for a Directive on the fight against fraud to the Union's financial interests by means of criminal law, COM (2012)363 final (July 11, 2012); Proposal for a Council Regulation on the establishment of the European Public Prosecutor's Office, COM (2013) 534 final (July 17, 2013).

${ }^{17}$ The criminal protection of the Community's financial interests: A European Prosecutor, COM (2000) 608 final (Sep. 29, 2000); Amended proposal for a Directive on the criminal-law protection of the Community's financial interests, 2003 O.J. (71E) 1; Green Paper on criminal-law protection of the financial interests of the Community and the establishment of a European Prosecutor, COM (2001) 715 final (Dec. 11, 2001).

18 Proposal for a Regulation of the European Parliament and the Council on the European Union Agency for Criminal Justice Cooperation (Eurojust), COM (2013) 535 final (July 17, 2013). 
Union's financial interests; the struggle of Member States to retain sovereignty over a highly emblematic field; and the consolidation of the EU project.

\section{RJR and the Surprising Virtues of EU Private International Law: What Would Happen if a Foreign Plaintiff Sued a European Corporation in the European Union for Similar Illegal Conduct?}

In RJR, the Supreme Court refused to adopt a "double standard" discriminating according to the identity of the plaintiff in order to permit extraterritorial suits when the plaintiff is a foreign sovereign who could certify that foreign sovereign dignity is not at stake. "After all, in the law, what is sauce for the goose is normally sauce for the gander" says the Court. ${ }^{19}$ The point is understandable in regard to RICO's features. Under RICO, private claims have a public dimension and criminal offenses have a private counterpart. This is the trigger for treble damages and the specificity of the regulatory choice behind RICO.

On the other side of the Atlantic, would a foreign public authority find any equivalent to RICO and be able to litigate a claim relating to criminal offenses committed by a European Union-based corporation? And would the goose and the gander share the same sauce? The starting point is that, in the European Union, there is no equivalent to RICO offering a private right of action to both public and private plaintiffs in case of a criminal offense. The case would thus unfold in a very different way depending on the identity of the plaintiff and be structured along the lines of the public-private divide. In a nutshell, the foreign public authority would rarely have access to EU civil courts if it were acting in the exercise of its public power, for instance when trying to recover lost custom revenues. ${ }^{20}$ The claim would most likely be considered as falling within the realm of public law. ${ }^{21}$ The public avenue, on the other hand, is not a practical option. Criminal prosecutors or tax administrators do not implement foreign criminal or taxation law, but can collaborate with foreign authorities under specific cooperation agreements. ${ }^{22}$ Upon the reception of information transmitted by a foreign public authority, national criminal authorities of Member States could prosecute crimes partially or entirely committed abroad by an European Union-based company, but only to the extent that their own criminal law penalizes such acts "extraterritorially" - and not in order to redress specific damages supported by a foreign sovereign. ${ }^{23}$

The situation of a private plaintiff in contrast seems more favorable. If a criminal action were pending in the European Union, the victim could in most instances join a civil claim for damages to the criminal litigation, without additional conditions for establishing jurisdiction on the civil claim. ${ }^{24}$ In the absence of criminal proceedings, the victim can also bring a claim for damages before the civil courts. Such a claim would be subject to the technical machinery of EU private international law-its categories and specific structuring of the proceedings. When the defendant is domiciled in the European Union, jurisdiction is determined by the Brussels

${ }^{19} \underline{\mathrm{RJR}}, 136$ S. Ct. at 2108, slip op. at 22.

${ }^{20}$ Regulation $1215 / 2012$ of 12 December 2012 on jurisdiction and the recongnition and enforcement of judgements in civil and commercial matters (Regulation Brussels Ibis), 2012 O.J. (L 351) [hereinafter Regulation 1215/2012]. See, e.g., Case C- 645/11, Land Berlin v. Sapir paras. 33, 34.

21 But see Case C-49/12, The Commissioners for Her Majesty's Revenue \& Customs v. Sunico paras 38-40.

22 Eurojust has cooperation agreements with third states and Liason Prosecutors for those states (including the United States, see for instance, Eurojust, Annual Report 2015, 47).

${ }^{23}$ Criminal jurisdiction over criminal activities can sometimes be asserted on the basis of the nationality or residence of the defendant, see for instance Council Framework Decision 2008/841/JHA of 28 october 2008 on the fight against organised crime, art. 7, 2008 O.J. (L 300) 42; Art. 11 of the future PIF Directive as amended by Parliament (Position of the European Parliament adopted at first reading on 16 April 2014, Eur. PArL. Doc. P7_TA(2014)0427); Proposal for a Directive of the European Parliament and the Council on combating terrorism art. 21, COM (2015) 625 final (Dec. 2, 2015).

${ }^{24}$ Regulation 1215/2012 art.7 (3); Directive 2012/29 of 25 October 2012 establishing minimum standards on the rights, support and protection of victims of crime art. 16, 2012 O.J. (L 315) 57. 
I bis Regulation, which offers three possible jurisdictional grounds: the claim could be brought in the Member State where the defendant is domiciled or where the damage or the event giving rise to liability took place. ${ }^{25}$ Even if the injury and the illegal conduct have taken place abroad, a European Union-based corporation can thus be sued for damages at the place of its domicile in the European Union. But this is only the beginning of the case: once jurisdiction is granted in a Member State, the court will have to determine the applicable law according to conflict rules. Unlike in criminal proceedings, the questions of jurisdiction and applicable law are decoupled.

This machinery allowed, for example, Nigerian farmers to sue Shell in the Netherlands for injury suffered in Nigeria following an oil spill and to join the Nigerian subsidiary as a defendant. ${ }^{26}$ Of course, the defendants argued that a case between Nigerian parties concerning facts that occurred in Nigeria should be litigated in Nigeria. But because jurisdiction was based on a fixed and straightforward criterion in the Brussels Ibis Regulation, and because jurisdiction was not dependent on the applicable law, the case did not raise the dramatic discussion on extraterritoriality that took place in the United States in the slightly different context of Kiobel. In other words, the technical aspect of EU private international law defuses the debate and sometimes brings surprisingly positive results in terms of social justice. ${ }^{27}$ But this conclusion should not overshadow the fact that the civil litigation brought in the European Union would lack the powerful features of a RICO proceeding in the United States. Civil jurisdiction opens the way to claiming civil damages under the applicable law: this usually leads to the general provisions on ordinary extracontractual liability of that law. Depending on the facts of the case, the applicable law might be that of a Member State or that of a third state. In any case, treble or punitive damages are virtually unknown in the European Union. Even the EU Directive on private enforcement of competition law forbids "overcompensation, whether by means of punitive, multiple or other types of damages." 28 The EU civil litigation avenue therefore offers no direct equivalent to the type of private enforcement possible under RICO.

\section{Conclusion}

To be sure, I disagree with the decision reached in RJR, precisely for the reasons given by Justice Ginsburg. But looking at the European side of the picture sheds additional light on the policy dimensions of the decision: can "we" blame foreign courts for not offering us what "we" are not capable of providing for ourselves and to foreign plaintiffs? The facts at the heart of RJR underline some of the regulatory features and maybe some vulnerabilities of the EU system.

In 2000, the weaknesses of EU criminal law led the European Community to export a criminal case affecting its own financial resources and market. The Commission had clearly identified the weak spots and already proposed the establishment of a European Public Prosecutor. But the construction of such a "federal" criminal authority was then thought to be completely at odds with the tradition of decentralized application of EU law and, most importantly, with the sovereignty claims of Member States. From this perspective, sixteen years for achieving such a major innovation does not seem unreasonable; it is exactly the time it took to litigate in the

${ }^{25}$ Regulation 1215/2012 art. 4(1) and art. 7(2) as interpreted by the ECJ (Case 21/76, Handelskwekerij G. J. Bier BV v Mines de potasse d'Alsace SA , 1976 E.C.R. 01735).

26 See Outcome appeal against Shell: victory for the environment and the Nigerian people, MILIEUDEFENSIE When the case is brought at the place where the defendant is domiciled (here Shell Netherlands), Brussels Ibis or equivalent national procedural rules allow for joining related claims against other defendants (here Shell Nigeria).

${ }^{27}$ For similar findings, see Karen Knop et al., From Multiculturalism to Technique: Feminism, Culture and the Conflict of Laws, 64 STAN. L. REV. 589.

${ }^{28}$ Directive 2014/104 of 24 November 2014 on certain rules governing actions for damages under national law for infringements of the competition law provisions of the Member States and of the European Union art. 3, 2014 O.J. (L 349$) 1$. 
United States. In 2016, the European Union still does not offer the equivalent of a RICO private right of action to foreign victims of illegal conduct by European Union-based companies. Based on a sharp public-private divide, the situation is precarious for foreign public authorities, while private plaintiffs have a more straightforward access to jurisdiction. The existence of predetermined jurisdictional grounds and the absence of forum non conveniens avoid dramatic debates on grand doctrines such as extraterritoriality. But, in the end, EU substantive law does not offer any powerful form of private enforcement equivalent to RICO's treble damages. 